\title{
Exploring Malaysia Public Private Partnership Success
}

Rafedzah binti Mohd Som, Ismi Arif bin Ismail, Soaib bin Asimiran, Siti Noormi binti Alias, Zoharah binti Omar

To Link this Article: http://dx.doi.org/10.6007/IJARBSS/v11-i12/11699

DOI:10.6007/IJARBSS/v11-i12/11699

Received: 05 October 2021, Revised: 07 November 2021, Accepted: 27 November 2021

Published Online: 16 December 2021

In-Text Citation: (Som et al., 2021)

To Cite this Article: Som, R. binti M., Ismail, I. A. bin, Asimiran, S. bin, Alias, S. N. binti, \& Omar, Z. binti. (2021). Exploring Malaysia Public Private Partnership Success. International Journal of Academic Research in Business and Social Sciences, 11(12), 1911-1926.

\section{Copyright: (c) 2021 The Author(s)}

Published by Human Resource Management Academic Research Society (www.hrmars.com)

This article is published under the Creative Commons Attribution (CC BY 4.0) license. Anyone may reproduce, distribute, translate and create derivative works of this article (for both commercial and non0-commercial purposes), subject to full attribution to the original publication and authors. The full terms of this license may be seen at: http://creativecommons.org/licences/by/4.0/legalcode

Vol. 11, No. 12, 2021, Pg. 1911 - 1926

Full Terms \& Conditions of access and use can be found at http://hrmars.com/index.php/pages/detail/publication-ethics 


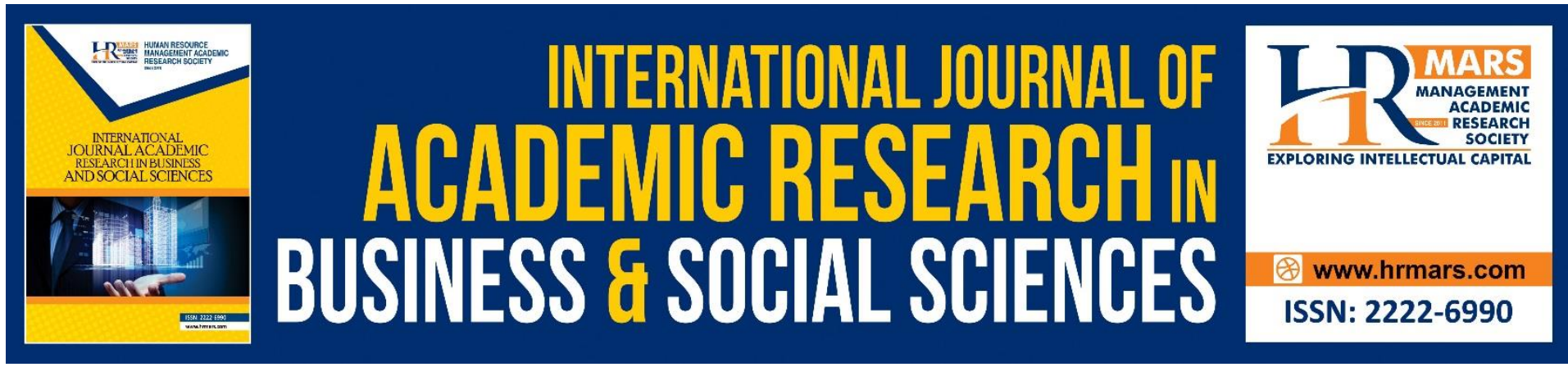

\title{
Exploring Malaysia Public Private Partnership Success
}

\author{
Rafedzah binti Mohd Som, Professor Dr. Ismi Arif bin Ismail, \\ Associate Professor Dr. Soaib bin Asimiran, Dr. Siti Noormi \\ binti Alias, Dr. Zoharah binti Omar \\ Faculty of Educational Studies, Universiti Putra Malaysia \\ Email: rafedzah75@gmail.com, ismi@upm.edu.my,soaib@upm.edu.my, \\ sitinoormi@upm.edu.my,omarzoharah@gmail.com
}

\begin{abstract}
Even though the Public Private Partnership (PPP) program has been implemented in many countries, assessing the program success is limited. Thus, the purpose of this paper is to explore what PPP success is from the perspective of the critical players of PPP in Malaysia, i.e. the public and the private partners. This study is a qualitative research design where data was gathered through open-ended questionnaires, interviews, and emails. Data has been analysed using the constant comparative method. Respondents have been selected by purposive sampling from both the private and public sectors. The findings of this study recognised that both the public and the private sector are agreeable to what successful PPP is. Also, the results propose that PPP success be viewed from two different perspectives, i.e. process measurement and outcome measurement.
\end{abstract}

Keywords: Malaysia PPP, Outcome Success, Process Success, Public-Private Partnership, Successful PPP.

\section{Introduction}

Even though many types of research have been carried out on PPPs, there is generally no acceptable definition of PPP (Warsen et al., 2018). Likewise, the broad definition or conceptualisation of PPP success is still unclear. Only recently; attempts to conceptualise and measure PPP success have been made. The concept of PPP success is difficult to be agreed. In PPP settings, the public and the private sector may hold different perspectives of PPP success due to their different objective of existence (Dowling et al., 2004; Yuan et al., 2012). While one partner is a social-oriented entity, the other partner is a profit-oriented organisation (Zou et al., 2014). This paper attempts to explore what PPP success is from the perspective of the key players of Malaysia PPP, i.e. the public and the private partners.

\section{Background}

Generally, PPP can be referred to as the contractual involvement between the public and the private sectors in infrastructure development (Ahmad et al., 2018a; Ismail \& Harris, 2014; Yuan et al., 2009). The level of involvement between the public and the private sectors may 
depend on many factors such as the degree of risk-sharing (Yuan et al., 2010) or region and type of projects implemented (Ahmad et al., 2018a; Carbonara et al., 2013). It also depends on the unique qualities of each adopting country (Ismail \& Haris, 2014; Mohamad et al., 2018b). At least in Malaysia, the PPP arrangement referred to a contractual working relationship between the public and the private sector in a project management setting.

The history of Malaysia's PPP can be traced back to the 1980s, when the government introduced many initiatives to encourage the participation of the private sectors in the delivery of public facilities (Sapri et al., 2016). It was done through the introduction of (The Malaysia Incorporated Policy 1981; Privatisation Policy, 1985; (The Privatisation Master Plan, 1991). To strengthen the participation of private sectors, PPP has been introduced formally under the Tenth Malaysia Plan, incorporating privatisation and Public Finance Initiative (PFI) (Ismail, 2013; Rashid et al., 2016). Accordingly, RM63 billion has been allocated for PPP projects under the Tenth Malaysia Plan (Government of Malaysia, 2009).

PPP in Malaysia involves the transfer to the private sector the responsibility to finance and manage a package of capital investment and services, including the construction, management, maintenance, refurbishment and replacement of the public sector assets, which creates a standalone business (UKAS, 2009). There is a contract for the private party to deliver public facilities and services within the PPP relationship. They will have to raise their funds to finance the development and delivery of the facility for an agreed concession period. Payment from the government will be based on an agreed performance level, such as the quality and timeliness of the services. In some cases, the private partners will receive payment from users' charges levied directly on the end-users; or sometimes both from the government and the end-users.

PPP is different from the traditional procurement method. In a 'build and deliver' mechanism, private companies will construct infrastructure or services specified by the government through tender or direct negotiations. Once the construction is completed, the asset will be transferred and operated by the government (Burger \& Hawkesworth, 2011). On the other hand, the PPP arrangement was structured. It is agreed for the private sector to finance and manage a package of capital investment and services, including the construction, management, maintenance, refurbishment, and replacement of the public sector facilities. In return, the private sector will be compensated according to the levels, quality and timeliness of the service delivery specified in the concession agreement (Carbonara et al., 2013).

As the conventional procurement activities will take only a few years to be completed, the relationship between the public and the private sector is based on a contractor-principal relationship. However, a PPP arrangement involves a much longer cooperative relationship between the public and the private sector as they are bounded by a longer duration of concession agreement (Burger \& Hawkesworth, 2011; Yuan et al., 2008).

This long-term arrangement makes PPP more complicated to be measured successfully than the 'build and deliver' mechanism. Due to the nature of the longer-term contractual relationship, it is crucial to assess PPP success in terms of process and output performance. In other words, PPP success measurement should not solely involve dollar and cent but also 
the level of the working relationship; i.e. partnership relationship healthiness between the public and the private sector (Salve et al., 2018; Singaravelloo, 2010; Warsen et al., 2019).

Also, even though a regular project in a conventional setting is characterised by multidisciplinary individuals from many departments (Meredith \& Mantel, 2009), their ultimate organisational objective remains the same. In this regard, the PPP working environment is more complex. In a PPP setting, besides having different expertise, members also represent two different organisations, i.e. the public and the private sector, and thus have contrasting objectives. While the former is a social-oriented organisation, the latter is a profit-oriented focused organisation. Therefore, their different purpose of existence may affect their perception of PPP success.

\section{Literature Review}

Generally, past studies have broadly categorised the concept of PPP success in two ways, i.e. process and outcome.

\section{Process Success}

Process success could be defined simply as the achievement of a structured, measured set of activities across time and place with a beginning and an end. It begins with identifying inputs and accomplishing a specific goal of outputs (Torraco, 2005). PPP process success can be conceptualised in two ways. Firstly, process success is related to the partnership working relationship, i.e. 'the extent to which the pattern of interactions is acceptable to the partners' (Ariño, 2003, p.75). For example, through the level of trust, commitment, coordination and communication between partners (Mohr \& Spekman, 1994; Warsen et al., 2018, 2019).

Yung et al (2005) have measured the level of attitude of the public and the private psychiatry towards shared care arrangement between the public and the private sector as a proxy to measure the success of their collaboration. In a recent PPP study, Warsen et al (2018) have included respondents perception of the partnership process as an indicator of PPP process success. They label respondents' perception of the partnership process as the 'quality of cooperation' and measure it through three dimensions: managing internal conflicts, presence of deadlocks, and course of cooperation.

Past researchers have also acknowledged that partnership process success is as critical as outcome success. Understanding outcome success must begin by understanding how process factors interact (Ariño, 2003; Dowling et al., 2004). The measurement of partnership process success focuses on the level of working relationship between partners, i.e. the health of the partnership. Past studies have shown that members interaction plays a prominent role in determining partnership success (Mohr \& Spekman, 1994). While working together, the interpersonal level interaction will determine whether the partner's team members trust and like each other. In return, it will determine how effective the partnership is at the organisational level (Prati et al., 2003). The reason is that a healthy interpersonal relationship between members of the different partners will act as an 'informal self-enforcing agreement' that facilitate the organisational level partnership to thrive (Dyer and Singh, 1998a; Sambasivan et al., 2011; p.553). 
Secondly, PPP process success can be conceptualised based on the favourable working environment that influences partnership success (Dowling et al., 2004). Researchers examined various critical success factors that contribute to PPP success from these perspectives. For example, some researchers have measured respondents' perception of the importance of the available financial market, broader interagency activities; suitable institutional and legal structures, good governance, commitment and responsibility of partners, sound economic policy and the availability of the financial market towards PPP success (Cheung et al., 2012; Ismail, 2013; Muhammad \& Johar, 2019).

\section{Outcome Success}

On the other hand, the outcome can be defined as the result or effect of an action, event or situation. Weldon and Weingart (1993) defined outcome success as the degree of achieving a set of activities in accomplishing stated objectives. Past studies indicated that the concept of PPP outcome success had been measured in several ways:

\section{(i) PPP Key Performance Indicators}

Early studies in PPP performance have identified critical key performance indicators (KPIs) to measure PPP achievement. As PPP central activities are project management, many PPP key performance objective indicators are similar to those used to measure project management success (Cooke-Davies, 2002; Muller \& Jugdev, 2012; Pinto \& Slevin, 1988; Xiong et al., 2015; Yuan et al., 2009). For example, indicators such as within budget, the project completed on time and acceptable quality of the infrastructure are common KPIs in measuring project and PPP management success (Mohamad et al., 2018a; Nixon et al., 2012).

Also, to some extent, both the public and the private partners agree on similar KPIs in measuring PPP outcome success. For example, both partners perceived quality, cost and time as necessary indicators in measuring PPP projects achievement (Yuan et al., 2009). Likewise, Yuan et al (2010) have proposed fifteen PPP performance objectives attributes based on the perspectives of different stakeholders. The researchers found that different stakeholders prefer different performance indicators but generally agreed that cost, time, and quality are essential indicators in measuring PPP project success.

Similarly, Mohamad et al (2018a) have identified respondents' perceptions of the critical performance indicators to assess Malaysia PPP performance. They found that 'operational cost'. 'construction cost', and 'construction period' are among the top key performance indicators preferred to indicate PPP achievement. Among others, Mohamad, Ismail, \& Mohd Said (2018a) 's findings provide the basis that PPP project success must be considered an element in conceptualising Malaysia's PPP success.

Interestingly, regardless of whether they represented the public or the private partners, primary performance objective indicators such as acceptable quality of the project, within budget, good quality of public service and on-time or earlier project completion have been preferred to indicate PPP performance both in Hong Kong (Xiong et al., 2015) and in Malaysia (Mohamad, Ismail and Said, 2018). These findings show that to some extent, as partners, the public and private sectors have a shared vision and goals in undertaking PPP projects. In partnership, having common and shared goals is essential to indicate that both parties are on the same page to achieve shared objectives (Zhang, 2006 as cited by Xiong et al., 2015). 
(ii) PPP Project Success

PPP project success has been defined as the 'delivery of the desired service quality to the beneficiaries at a scheduled time in budgeted cost that satisfies the major stakeholders, i.e. equity provider, Special Purpose Vehicle/Private Partner, government and beneficiaries' (Ahamd, Ibrahim, \& Abu Bakar, 2018, p. 36). The definition was proposed based on the interviews quotations using Atlas ti 8.0. This definition is consistent with the general description of project success. For example, Wit (1988) has defined project success as 'the project is considered an overall success if the project meets the technical performance specification and/or mission to be performed, and if there is a high level of satisfaction concerning the project outcome among key people in the parent organisation, key people in the project team and key users or clientele of the project effort' (p.165). His proposition was based on a structured literature review.

Warsen et al (2018) used perceived project performance to proxy for PPP outcome. In their research, respondents were asked to rate their perception of the project's performance through five dimensions: integral of the solution, the solution's effectiveness, effectiveness in the future, support for the solution, and the relation between cost and benefits. Perceive project performance is adopted because it is challenging to select indicators that best represent the objectives of PPP success for both the public and the private sector.

\section{Stakeholders' Satisfaction}

Lastly, affective measurement such as stakeholders' and end-users satisfaction has also been proposed to measure PPP outcome success (Yuan et al., 2008). For example, Warsen et al (2019) defines PPP project success as 'projects with outstanding performance' (p.6). They measure project performance as a combination of 'traditional' performance measures such as on-time delivery, budget delivery and value for money and a softer operationalisation of perceived performance (satisfaction). From the research point of view, a successful partnership project will only exist if both partners benefited from it. Thus, to determine the final scores, the researcher use' satisfaction on the project performance' in which very low satisfaction scores will resulted in lowering of project scores and vice versa. When there is a significant difference between the 'traditional' performance measure and satisfaction level, qualitative data interviews were held to examine the reasons for the differences.

\section{Research Methodology}

This research is based on the premise that partnership success should be evaluated through the process and outcome measurements (Asthana et al., 2002; Dowling et al., 2004). While process measurement focuses on the working relationship and the health of the partnership, the outcome measurement focuses on whether the partnership benefits the individual partners, the collaboration itself, and the intended end-users.

It is essential to distinguish the PPP success measurement as a process or an outcome because outcome performance is influenced by process performance (Ariño, 2003). In this regard, while the partnership process could be considered 'success', the intended partnership outcome may not be achieved (Greig \& Poxton, 2001). However, suppose the measurement of success is focused solely on the outcome; in that case, the partnership process's gain and benefits will be underestimated (Ansari et al., 2001). The lack of partnership process measurement will hinder effective intervention and facilitation of change required to 
enhance partnership progress and success (Asthana et al., 2002). It is because, while interacting formally or informally, individual partners may start to trust each other. Partnerships share new business insights, knowledge, and information by trusting each other. It also builds and enhances personal working relationships for the future sustainability of collaboration at the organisational level (Cullen, Johnson and Sakano, 2000; Whipple and Frankel, 2000; Casey, 2008; Ahmed and Anantatmula, 2017). Thus, this study will be focusing on both kinds of success; process and outcome.

This exploratory qualitative study uses the interpretative approach (Audet \& D'Amboise, 2001; Elliott \& Timulak, 2005; Merriam \& Tisdell, 2016). Data has been gathered through an in-depth interview technique with ten respondents that have been chosen based on the purposive sampling method. This method was selected because the study required respondents who have expertise and experience in PPP. Their perspective is critical to analyse in this research (Berenson, Levine, \& Szabat, 2015; Creswell, 2013). The criteria of the respondents that have been selected for the study were: (1) participants involvement in at least three PPP projects and (2) have been in a PPP team for at least three years. Respondents conforming to these criteria are believed to have enough PPP experience and, therefore, could provide the information required by this study.

The ten informants who participated in this study were from various organisations. Six of them were from the public sector, and the rest were participants from the private sector. The majority of the participants have been involved in more than ten PPP projects. In protecting their confidentiality, informants from the public sectors have been assigned as Public 1 , Public 2, Public 3, Public 4, Public 5 and Public 6 . In contrast, informants from the private sectors will be known as Private 1, Private 2, Private 3 and Private 4.

Phone calls were followed by emails asking whether participants were interested in responding to the study's questions. They are informed that their confidentiality is assured, and as their participation was voluntary, they could withdraw at any time. The interviews were held around 40 minutes, recorded and later transcribed verbatim. The open-interview protocol was structured according to the focus of the study. It started with asking general inquiries on respondents' perceptions of PPP success is; followed by questions to clarify respondents' earlier answers. The subsequent questions are broad enough to hinder any indirect attempt to elicit specific responses throughout the interview period (Merriam \& Tisdell, 2016).

\section{Results and Discussion}

The data has been analysed through the constant comparative method analysis (Creswell, 2013; Grove, 1988; Merriam \& Tisdell, 2016). In ensuring the study's validity, verbatim transcribed interviews were sent back to respondents for their feedback and agreement on the themes created (Creswell, 2013). Where necessary, revision and deletion to the verbatim script have been done. Follow up interviews were conducted with respondents to triangulate responses, and their responses were also corroborated with findings from past researchers. While analysing the data through the constant comparative method, respondents' answers to PPP success were grouped into 'process measurement' and 'outcome measurement' categorisation. 


\section{Process Measurement}

The study found that three out of the ten respondents mentioned that PPP success should be looked at from the 'process measurement' perspective. The process measurement variables mentioned by respondents are similar to past studies' findings in partnership, PPP or project success. The mentioned process measurement variables are effective leadership, good cooperation, and a balanced relationship.

For example, Private 4 proposed that PPP is a success when 'there are effective leadership and good relationship between the government and the private sector to achieve the common objectives.' Just like in a typical setting organisation, leadership has also been acknowledged as the success driver of partnership (Dowling et al., 2004), project (Ahmed \& Anantatmula, 2017; Müller \& Turner, 2010) and PPP (Singaravelloo, 2010). Besides performing their daily operation activities of managing projects, PPP leaders play an essential role in fostering a good relationship between both parties by demonstrating power sharing and negotiation readiness behaviour (Casey, 2008; Lop et al., 2016; Singaravelloo, 2010; Yuan et al., 2008). PPP leaders are expected to galvanise the cooperation of various individuals with diverse expertise from different organisations. They are also required to cultivate trust between their team members and their partners' team members. Trust is the fundamental element to facilitate human interaction, especially during the initial stages (Anantatmula, 2010) and develop a partnership relationship (Cullen et al., 2000; Whipple and Frankel, 2000; Casey, 2008).

Private 4 further explained that a good relationship means that the public and the private sector are governed based on trust, openness, and fairness. These three variables have been acknowledged as characteristics of a successful partnership in many past studies (Mohr \& Spekman, 1994; Tuten \& Urban, 2001). However, it is also found that the same variables are the basic foundations underpinning successful PPP in Malaysia (Singaravelloo, 2010) and Lebanon (Jamali, 2004). Lack of trust, openness and fairness will hinder effective partnership as individuals involved will limit their involvement in the relationship (Casey, 2008). The lack of confidence had contributed to the hedging of risk behaviour among Malaysia's public and the private sector (Ahmad et al., 2017). Indirectly, the outcome of trust has contradicted the basic principle of PPP, i.e. risk should be allocated to the party best manage it.

The importance of having a good relationship between partners was supported by Private 1 . The respondents that a successful PPP happens when 'no one partner should feel above the other partner'. This view is based on the concept that a good partnership must demonstrate power sharing and negotiation readiness behaviour (Casey, 2008). Studies have shown that a power balanced partnership is more stable than an unbalanced relationship (Burgess \& Huston, 1983 as cited in Anderson \& Weitz, 1989). When partners perceive that their relationship is power balanced, they will work diligently to bring the partnership to success (Kingshott, 2006). However, an unbalanced power distribution will result in lower power partner's dissatisfaction, lack of cooperation and more significant conflicts (Dwyer et al., 1987). It might be due to the more vital partner manipulating the process or exploiting the partnership to their advantage (Ansell \& Gash, 2008; Anderson \& Narus, 1984).

It is important to note that respondents' perceptions of PPP success concerning process measurement are directly or indirectly related to 'human process' or socio factors that contributed to it. Their responses centralised on words such as 'effective leadership', 'good 
cooperation' and a 'balanced relationship between partners' are all associated with humans and their roles in a PPP setting. Thus, the findings indicate that it is essential to identify the underlying socio mechanism that drives these partners to work together.

\section{Outcome Measurement}

Nine out of ten respondents in this study shared a similar notion of the concept of a successful PPP. They defined successful PPP as meeting the respective stakeholders' primary objectives (objective outcome measurement) when entering a PPP agreement. The primary goals are projects with value-for-money to the government, return on investment for the private sector, and the end-user receiving the intended benefits. To Public 4, a successful PPP happens when;

'it meets the objectives set for in the agreement; value for money to the government, and at the same time, the private sector gets their profits. End-user must get the benefits. When a project is successful, it is a win-win situation'.

Private 3 concur with Public 4 if it 'met all stakeholder; Government of Malaysia, concessionaire, end-users and the strategic intents when they agreed to enter into PPP contracts.' It is also successful 'when targets are met; when the objectives of the projects during its conceptualisation and accepted are met' (Private 1).

These research findings are similar to Mohamad, Ismail and Said (2018) 's findings. In their research, it is found out that the five most important PPP's performance objectives (regardless of ranking) as perceived by the public and the private respondents are 'highquality of public service', 'provide convenient service for society', 'within or under budget, 'satisfy the need for more public facilities' and 'on-time or earlier project completion'. Also, these research findings are consistent with the results of Xiong et al (2015) and Zou et al (2014). The researchers found that the private sector maximises profit while the government prefers budget-saving. At the same time, the general public's wants better facilities than those facilities developed through conventional procurement methods.

In addition, Private 2 feels that PPP projects under his team can be considered successful because they have fully complied with the requirement of the concession agreement. To be regarded as a successful PPP, most respondents suggested the importance of achieving objectives spelt out in the concession agreement. In general, it stated that in return for the assets/infrastructures built or services provided by the government, the private sector is entitled to a percentage of agreed returns. Even though both the public and the private respondents relate successful PPP to the conforming of the concession agreement., their reasons for doing so might be different. The private sector realised that without conforming to the provision of the concession agreement, they would not receive any payments or payments in full (Mohamad et al., 2018b). Conformity to the concession agreement is critical to the public respondents because any contradictions must be managed effectively. It is because the public sector is accountable to the general public.

Lastly, it is interesting that none of the respondents mentioned any affective outcome measurement as an indicator of PPP success. These findings suggested that the achievement of the PPP performance objective is given more weightage than the affective measurement as they are more measurables and easily justified. 


\section{Conclusions}

In conclusion, public and private respondents generally have a similar perspective on successful PPP in Malaysia. The similarities of their answers show that the issues of different partners have a different concept of success does not apply at least in Malaysia PPP context. Having a shared perspective on PPP success is vital because partnership success depends on the public and the private partners having common objectives.

This similarity of common objectives understanding among the PPP players is a fundamental good start in ensuring successful implementation of PPP projects in Malaysia and sustaining the long journey together. It also indicated that Malaysia public-private partnership is on the same wavelength. This same wavelength situation will promote the level of commitment committed to the partnership, minimise conflict, develop trust and willingness for communication and execution among individuals involved in the partnership.

The research findings also indicate that both the public and the private partners understand different objectives of existence and the importance of these objectives to their respective partners. Both partners do acknowledge each other individual goals in entering a PPP agreement. They are willing to ensure that while the public and the private partner objectives may contradict one another, neither objective should be sacrificed. This acknowledgement shows that respondents, as the key players of PPP, had established a mutual understanding of PPP spirit, i.e. a win-win situation for all parties.

However, findings have also implied that none of the respondents relates it to a good working relationship in considering a successful PPP. The lack of emphasising a good quality of PPP working relationships signifies that it is vital for PPP key players to accentuate sound relational management principles. The awareness of the importance of a good working relationship between the public and the private sector must be asserted if private participation remains a vital role in Malaysia's future infrastructure development.

\section{Theoretical Contributions}

This study is based on the classical system theory of input-process-output. Even though system theory has been criticised for its inability to illustrate any knowledge domain in a most specific manner, it helps frame a conceptual situation relationship such as in a PPP setting (Carr-Chellman \& Carr-Chellman, 2020; Ju, 2019; Swanson et al., 2020; Thomassen et al., 2017). Understanding PPP process success will help appropriate intervention for the PPP outcome's success (Albert et al., 2017; Ariño, 2003; Dowling et al., 2004). For example, trust as process that contribute to PPP success. Furthermore, as the measurable PPP output may take a long time to materialise, it is not easy to objectively measure outcome success (Dowling et al., 2004). It is also difficult to attribute the partnership or PPP project success solely to the PPP project team due to the uncontrollable external forces. Thus, evaluating process success periodically might be a critical strategy to ensure that necessary organisational development intervention could be done to the problematical identified process variables. This intervention will ensure the achievement of the PPP process success and its influence on PPP outcome success (Dowling et al., 2004; Wit, 1988). Therefore, this research enlightens system theory's significance in a complex, non-linear environment like a PPP. 


\section{Research Limitation and Further Work}

Even though the results from the interviews were consistent with the existing literature, some limitations must be highlighted. First, due to time limitations, the research has to stop at ten respondents because no other respondents are willing to participate for the given period. Therefore, future studies may want to include more public and private respondents and focus on PPP success in terms of process measurement. We believe that the data collected, especially process measurement, has not reached saturation yet. Previous studies have found that many other process variables could influence PPP success.

The second limitation of this study is that it involves only two stakeholders of PPP projects. Even though the public and the private sectors play an essential direct role in PPP implementation, the general public as the end-users and paymaster could be the future respondents. Their contributions will ensure that the conceptual definition of PPP success will be much more comprehensive. Also, as the study had used the interview technique to gather data, the relationship between the process and the outcome of PPP in Malaysia could not be scientifically proven. Thus, a quantitative study may be held to investigate this relationship in the future.

Nevertheless, this research study provides insights into PPP knowledge and practical issues, at least in Malaysia. This study added to the literature on PPP implementation in Malaysia, especially in the PPP performance management area. Also, this study provides some helpful information to various PPP stakeholders, at least in the Malaysia PPP setting, on what successful PPP is from the perspective of the public and the private sector. Besides, in mentioning PPP success in terms of process measurement, all respondents have related successful process in terms of 'human process' and their roles in a PPP setting. These findings suggested that humans play an essential role in ensuring PPP success and thus called for future studies to deliberate further on this issue.

\section{References}

Ahmad, U., Ibrahim, Y., \& Abu Bakar, A. (2018a). Malaysian public private partnership. Academy of Accounting and Financial Studies Journal, 22(Special Issue), 1-6. https://www.scopus.com/inward/record.uri?eid=2-s2.085045730487\&partnerID $=40 \& m d 5=c 54 f b 7 a b 41 c b 3 e 092 d 03 f 0785 c 3 e 7 e 24$

Ahmad, U., Ibrahim, Y., \& Abu Bakar, A. (2018b). Malaysian public private partnership projects: project success definition. International Journal of Engineering \& Technology, 7(3.30), 33-37.

Ahmad, U., Ibrahim, Y., \& Minai, M. S. (2017). Public private partnership in Malaysia: The differences in perceptions on the criticality of risk factors and allocation of risks between the private and public sectors. International Review of Management and Marketing, 7(2), 138-150. https://ideas.repec.org/a/eco/journ3/2017-02-21.html

Ahmed, R., \& Anantatmula, V. S. (2017). Empirical study of project managers leadership competence and project performance. Engineering Management Journal. https://doi.org/10.1080/10429247.2017.1343005

Albert, M., Balve, P., \& Spang, K. (2017). Evaluation of project success: a structured literature review. International Journal of Managing Projects in Business, 10(4), 796-821. https://doi.org/10.1108/IJMPB-01-2017-0004 
Anantatmula, V. S. (2010). Project manager leadership role in improving project performance. Engineering Management Journal, 22(1), 13-22. https://doi.org/10.1080/10429247.2010.11431849

Anderson, E., \& Weitz, B. (1989). Determinants of continuity in conventional industrial channel dyads. Marketing Science, 8(4), 310-323. https://doi.org/10.1287/mksc.8.4.310

Anderson, J. C., \& Narus, J. A. (1984). A model of the distributor's perspective of distributormanufacturer working relationships. Journal of Marketing, 48(4), 62-74. https://doi.org/10.2307/1251511

Ansari, W. El, Phillips, C. J., \& Hammick, M. (2001). Collaboration and partnerships: Developing the evidence base. Health and Social Care in the Community, 9(4), 215-227. https://doi.org/10.1046/j.0966-0410.2001.00299.x

Ansell, C., \& Gash, A. (2008). Collaborative governance in theory and practice. Journal of Public Administration Research and Theory, 18(4), 543-571. https://doi.org/10.1093/jopart/mum032

Ariño, A. (2003). Measures of strategic alliance performance: An analysis of construct validity. Journal of International Business Studies, 34(1), 66-79. https://doi.org/10.1057/palgrave.jibs.8400005

Asthana, S., Richardson, S., \& Halliday, J. (2002). Partnership working in public policy provision: A framework for evaluation. Social Policy and Administration, 36(7), 780-795. https://doi.org/10.1111/1467-9515.00317

Audet, J., \& D'Amboise, G. (2001). The multi-site study: An innovative research methodology. The Qualitative Report, 6(2). https://nsuworks.nova.edu/tqr/vol.6/iss2/2

Berenson, M. L., Levine, D. M., \& Szabat, K. A. (2015). Basic Business Statistics (13th Editi). Pearson, United States.

Burger, P., \& Hawkesworth, I. (2011). How to attain value for money: Comparing PPP and traditional infrastructure public procurement. OECD Journal on Budgeting, 2011(1), 156. https://doi.org/10.1787/16812336

Carbonara, N., Costantino, N., \& Pellegrino, R. (2013). A three-layers theoretical framework for analysing public private partnerships: The Italian case. Organisation, Technology \& Management in Construction: An International Journal, 6(2), 799-810. https://doi.org/10.5592/otmcj.2013.2.5

Carr-Chellman, D. J., \& Carr-Chellman, A. (2020). Integrating Systems: the History of Systems from von Bertalanffy to Profound Learning. TechTrends, 5. https://doi.org/https://doi.org/10.1007/s11528-020-00540-1

Casey, M. (2008). Partnership - success factors of interorganizational relationships. Journal of Nursing Management, 16, 72-83. https://doi.org/10.1111/j.1365-2934.2007.00771.x

Cheung, E., Chan, A. P. C., \& Kajewski, S. (2012). Factors contributing to successful public private partnership projects: Comparing Hong Kong with Australia and the United Kingdom. Journal of Facilities Management, 10(FEBRUARY), 45-58. https://doi.org/10.1108/14725961211200397

Cooke-Davies, T. (2002). The "real" success factors on projects. International Journal of Project Management, 20(3), 185-190. https://doi.org/10.1016/S0263-7863(01)000679

Creswell, J. (2013). Qualitative Inquiry and Research Design: Choosing Among Five Approaches. In SAGE Publications (Third Edit). SAGE.

Creswell, J. W. (2013). Qualitative Inquiry \& Research Design (Third Edit). SAGE. 
Cui, C., Liu, Y., Hope, A., \& Wang, J. (2018). Review of studies on the public-private partnerships (PPP) for infrastructure projects. International Journal of Project Management, 36(5), 773-794. https://doi.org/doi:10.1016/j.ijproman.2018.03.004

Cullen, J. B., Johnson, J. L., \& Sakano, T. (2000). Success through commitment and trust: The soft side of strategic alliance management. Journal of World Business, 35(3), 223-240. https://doi.org/10.1016/S1090-9516(00)00036-5

Dowling, B., Powell, M., \& Glendinning, C. (2004). Conceptualising successful partnerships. Health and Social Care in the Community, 12(4), 309-317. https://doi.org/10.1111/j.1365-2524.2004.00500.x

Dwyer, F. R., Schurr, P. H., \& Oh, S. (1987). Developing buyer-seller relationships. Journal of Marketing, 51(2), 11.27. https://doi.org/10.2307/1251126

Dyer, J. H., \& Singh, H. (1998). The relational view: cooperate strategy and sources of interorganizational competitive advantage. The Academy of Management Review, 23(4), 660-679. https://doi.org/10.7880/abas.13.77

Elliott, R., \& Timulak, L. (2005). Descriptive and interpretive approaches to qualitative research. In J. Miles \& P. Gilbert (Eds.), A Handbook of Research Methods for Clinical and Health Psychology (pp. 147-159). Oxford University Press. https://doi.org/10.1093/med:psych/9780198527565.001.0001

Greig, R., \& Poxton, R. (2001). Nice Process - But Did Joint Commissioning Change Anyone's Life? Journal of Integrated Care, 9(2), 16-21. https://doi.org/10.1108/14769018200100013

Grove, R. W. (1988). An analysis of the constant comparative method. International Journal of Qualitative Studies in Education, 1(3), 273-279. https://doi.org/10.1080/0951839900030105a

Ismail, S. (2013). Critical success factors of public private partnership (PPP) implementation in Malaysia. Asia-Pacific Journal of Business Administration, 5(5), 212-225. https://doi.org/10.1108/17574321311304503

Ismail, S., \& Haris, F. A. (2014). Rationales for public private partnership (PPP) implementation in Malaysia. Journal of Financial Management of Property and Construction, 19(3), 188201. https://doi.org/10.1108/JFMPC-04-2014-0006

Ismail, S., \& Harris, F. A. (2014). Challenges in Implementing Public Private Partnership (PPP) in Malaysia. Procedia - Social and Behavioral Sciences, 164(August), 5-10. https://doi.org/10.1016/j.sbspro.2014.11.044

Jamali, D. (2004). Success and failure mechanisms of public-private partnerships (PPPs) in developing countries. Insights from the Lebanese context. International Journal of Public Sector Management, 17(5), 414-430. https://doi.org/10.1108/09513550410546598

Ju, B. (2019). The roles of the psychology, systems and economic theories in human resource development. European Journal of Training and Development, 43(1-2), 132-152. https://doi.org/10.1108/EJTD-02-2018-0020

Kingshott, R. P. J. (2006). The of psychological contracts upon trust and commitment within supplier-buyer relationships: A social exchange view. Industrial Marketing Management, 35(6), 724-739. https://doi.org/10.1016/j.indmarman.2005.06.006

Lop, N. S., Ismail, K., \& Isa, H. M. (2016). Performance assessment framework for private finance initiative projects in Malaysia. MATEC Web of Conferences 66, IBCC, 00049, 18. https://doi.org/10.1051/matecconf/20166600049 
Meredith, J. R., \& Mantel, S. J. (2009). Project Management - A Managerial Approach (Seventh Ed). John Wiley \& Sons.

Merriam, S. B., \& Tisdell, E. J. (2016). Qualitative research: A guide to design and implementation. In Jossey-Bass.

Mistarihi, A., Hutchings, K., \& Shacklock, A. (2013). Differing opinions do not spoil friendship: Managing public-private partnership (PPP) infrastructure projects in Jordan. Public Administration and Development, 1-18. https://doi.org/10.1002/pad.1651

Mohamad, R., Ismail, S., \& Mohd Said, J. (2018a). Performance indicators for public private partnership (PPP) projects in Malaysia. Journal of Economic and Administrative Sciences, 34(2), 137-152. https://doi.org/10.1108/JEAS-04-2017-0018

Mohamad, R., Ismail, S., \& Mohd Said, J. (2018b). Performance objectives of public private partnership implementation in Malaysia: Perception of key players. Journal of Asia Business Studies, 12(1), 17-30. https://doi.org/10.1108/JABS-09-2015-0167

Mohr, J., \& Spekman, R. (1994). Characteristics of partnership success: Partnership attributes, communication behavior, and conflict resolution techniques. Strategic Management Journal, 15(2), 135-152. https://doi.org/10.1002/smj.4250150205

Muhammad, Z., \& Johar, F. (2019). Public-private partnership for housing construction projects a comparative analysis of the success factors between Malaysia and Nigeria. IOP Conference Series: Materials Science and Engineering, 1-11. https://iopscience.iop.org/article/10.1088/1757-899X/620/1/012007/pdf

Muller, R., \& Jugdev, K. (2012). Critical success factors in projects - the elucidation of project success. International Journal of Managing Projects in Business, 5(4), 757-775. https://doi.org/10.1108/17538371211269040

Müller, R., \& Turner, J. R. (2010). Attitudes and leadership competences for project success. Baltic Journal of Management, 5(3), 307-329. https://doi.org/10.1108/17465261011079730

Nixon, P., Harrington, M., \& Parker, D. (2012). Leadership performance is significant to project success or failure: a critical analysis. International Journal of Productivity and Performance Management, 61(2), 204-216. https://doi.org/10.1108/17410401211194699

Pearson, J. N., Carter, J. R., \& Peng, L. (1998). Alliances, logistics barriers, and strategic actions in the People's Republic of China. International Journal of Purchasing and Materials Management, 34(3), 27-36. https://doi.org/10.1111/j.1745-493X.1998.tb00293.x

Pinto, J. K., \& Slevin, D. P. (1988). Project success: definition and measurement techniques. In Project Management Journal (Vol. 19, Issue 3, pp. 67-73).

https://www.pmi.org/learning/library/project-success-definitions-measurementtechniques-5460

Prati, L. M., Douglas, C., Ferris, G. R., Ammeter, A. P., \& Buckley, M. R. (2003). Emotional intelligence, leadership effectiveness, and team outcomes. International Journal of Organizational Analysis, 11(1), 21-40. https://doi.org/10.1108/eb028961

Rashid, K. A., Hasan, S. F., Fauzi, P. N. F. N. M., Aripin, S., \& Sharkawi, A. (2016). A review on the Malaysian public private partnership (PPP). Journal of Scientific Research and Development, 3(4), 112-117. http://jsrad.org/wp-content/2016/Issue 4, 2016/19jj.pdf

Salve, S., Harris, K., Sheikh, K., \& Porter, J. D. H. (2018). Understanding the complex relationships among actors involved in the implementation of public-private mix (PPM) for TB control in India, using social theory Lucy Gilson. International Journal for Equity in Health, 17(1). https://doi.org/10.1186/s12939-018-0785-1 
Sambasivan, M., Siew-Phaik, L., Abidin Mohamed, Z., \& Choy Leong, Y. (2011). Impact of interdependence between supply chain partners on strategic alliance outcomes. Management Decision, 49(4), 548-569. https://doi.org/10.1108/00251741111126486

Sapri, M., Hariati, A. H., Sheau Ting, L., \& Sipan, I. (2016). Public private partnership benefits in delivering public facilities in Malaysia. MATEC Web of Conferences 66, IBCC, 00014, 1-7. https://doi.org/10.1051/matecconf/20166600014

Singaravelloo, K. (2010). PPP: The right marriage between local government and the private sector in Malaysia? International Journal of Institutions and Economies, 2(2), 142-166. https://core.ac.uk/download/pdf/6293774.pdf

Swanson, D., Goel, L., Francisco, K., \& Stock, J. (2020). Understanding the relationship between the general and middle-range theorising. The International Journal of Logistics Management, in-press. https://doi.org/10.1108/IJLM-04-2019-0120

Thomassen, O. J., Heggen, K., \& Strand, R. (2017). Applying principles of sociotechnical systems onto working environment research. Nordic Journal of Working Life Studies, 7(S2), 51-65. https://doi.org/10.18291/njwls.v7iS2.96690

Torraco, R. J. (2005). Work design theory: A review and critique with implications for human resource development. Human Resource Development Quarterly, 16(1), 85-109. https://doi.org/10.1002/hrdq.1125

Tuten, T. L., \& Urban, D. J. (2001). An Expanded Model of Business-to-Business Partnership Formation and Success. Industrial Marketing Management, 30(2), 149-164. https://doi.org/10.1016/S0019-8501(00)00140-1

Warsen, R., Klijn, E. H., Koppenjan, \& Joop. (2019). Mix and match: How contractual and relational conditions are combined in successful public private partnership. Journal of Public Administration Research and Theory, 29(3), 1-19.

https://doi.org/10/1093/jopart/muy082

Warsen, R., Nederhand, J., Klijn, E. H., Grotenbreg, S., \& Koppenjan, J. (2018). What makes public-private partnerships work? Survey research into the outcomes and the quality of cooperation in PPPs. Public Management Review. https://doi.org/10.1080/14719037.2018.1428415

Weldon, E., \& Weingart, L. R. (1993). Group goals and group performance. British Journal of Social Psychology, 32, 307-334. https://doi.org/10.1111/j.2044-8309.1993.tb01003.x

Whipple, J. M., \& Frankel, R. (2000). Strategic Alliance Success Factors. The Journal of Supply Chain Management, 36(3), 21-28. https://doi.org/10.1111/j.1745493X.2000.tb00248.x

Wit, A. de. (1988). Measurement of project success. International Journal of Project Management, 6(3), 164-170. https://doi.org/10.1016/0263-7863(88)90043-9

Xiong, W., Yuan, J.-F., Li, Q., \& Skibniewski, M. J. (2015). Performance objective-based dynamic adjustment model to balance the stakeholders' satisfaction in PPP projects. Journal of Civil Engineering and Management, 21(5), 539-547.

https://doi.org/10.3846/13923730.2014.895409

Yuan, J., Skibniewski, M. J., \& Li, Q. (2008). Managing the performance of public private partnership projects to achieve value for money: Key performance indicators selection. CIB W112 International Conference on Multi-National Construction Projects: Securing High Performance through Cultural Awareness and Dispute Avoidance', Shanghai, China 21-23 November 2008, 1-16. https://www.irbnet.de/daten/iconda/CIB12188.pdf 
Yuan, J., Skibniewski, M. J., Li, Q., \& Zheng, L. (2010). Performance objectives selection model in public-private partnership projects based on the perspective of stakeholders. Journal of Management in Engineering, 26(2), 89-104. https://doi.org/10.1061/(ASCE)ME.1943-5479.0000011

Yuan, J., Wang, C., Skibniewski, M. J., \& Li, Q. (2012). Developing key performance indicators for public-private partnership projects: Questionnaire survey and analysis. Journal of Management in Engineering, 28(July), 252-264. https://doi.org/10.1061/(ASCE)ME.1943-5479

Yuan, J., Zeng, A. Y., Skibniewski, M. J., \& Li, Q. (2009). Selection of performance objectives and key performance indicators in public-private partnership projects to achieve value for money. Construction Management and Economics, 27(3), 253-270. https://doi.org/10.1080/01446190902748705

Yung, A., Gill, L., Sommerville, E., Dowling, B., Simon, K., Pirkis, J., Livingston, J., Schweitzer, I., Tanaghow, A., Herrman, H., Trauer, T., Grigg, M., \& Burgess, P. (2005). Public and private psychiatry: Can they work together, and is it worth the effort? Australian and New Zealand Journal of Psychiatry, 39(1-2), 67-73. https://doi.org/10.1111/j.14401614.2005.01511.x

Zou, W., Kumaraswamy, M., Chung, J., \& Wong, J. (2014). Identifying the critical success factors for relationship management in PPP projects. International Journal of Project Management, 32(2), 265-274. https://doi.org/10.1016/j.ijproman.2013.05.004 